\title{
CORRIGENDUM
}

\section{The effect of political trust and trust in European citizens on European identity - CORRIGENDUM}

\author{
SOETKIN VERHAEGEN, MARC HOOGHE AND ELLEN QUINTELIER
}

doi:10.1017/S1755773915000314, Published online by Cambridge University Press, 30 September 2015

The authors have requested that Ellen Quintelier be added to the list of authors. The above published article was submitted to European Political Science Review without her name.

The correct list of authors is: Verhaegen, Hooghe \& Quintelier.

This error has now been rectified in the online article and the contents of European Political Science Review 9.2.

\section{Reference}

Verhaegen, S., M. Hooghe and E. Quintelier (2017) 'The effect of political trust and trust in European citizens on European identity', European Political Science Review 9(2): 161-181. doi:10.1017/ S1755773915000314. 